J. Environ. Sci.

Institute of Environmental Studies and Research - Ain Shams University

\title{
PRODUCTION OF BIODIESEL USING WASTE FAT FROM ROASTED CHICKEN
}

Heba M. Mohamed ${ }^{(1)}$; Taha M. A. Razak ${ }^{(2)}$ and Hamed A. Derbala ${ }^{(3)}$ 1) Professional Safety and Health at the National Center for Occupational Safety and Health Studies 2) Institute of environmental studies and research, Ain Shams University 3) Faculty of Science, Ain Shams University

\begin{abstract}
Fossil fuels are non-renewable sources of energy which generate pollutants and are linked to global warming and climatic change. In order to overcome these problems, there is a need for an alternative for fossil fuels. The most common renewable fuel is biodiesel which is produced from vegetable oils, animal fat wastes and poultry. The aim of the present work was to study the transesterification of liquid fat resulted from chicken roasting. This fat was esterified with methanol and $\mathrm{NaOH}$ as a basic catalyst. Product yield of chicken fatty acid methyl Ester (CFME) was $79.1 \%$ for liquid fat resulted from roasting. All quality control parameters for biodiesel produced (B100) were generally in agreement with ASTM standards. It can be concluded that chicken fat resulted from roasting is suitable for low cost feed stocks for biodiesel production.
\end{abstract}

Key words: biodiesel, liquid fat resulted from roasting, transesterification.

\section{INTRODUCTION}

Our society is highly dependent on petroleum for its activities. However, petroleum is a finite source and causes several environmental problems such as rising carbon dioxide levels in the atmosphere. About $90 \%$ of fossil fuels is used as an energy source for transportation, heat and electricity generation, and the remaining sources used as feed stocks in the chemical industry (Carlsson, 2009). Due to the increase in energy consumption and limitation of 
fossil fuels, research is directed towards alternative renewable fuels (Bhatti et al., 2008).

Biodiesel fuels are attracting increasing attention worldwide as a blending component or a direct replacement for diesel fuel in vehicle engines. Biodiesel consists of a mixture of fatty acid (chain length C14-C22) alkyl esters, derived from a renewable lipid feedstock, such as vegetable oil or animal fat. In the case of using methanol or ethanol is used as reactants, it will be a mixture of fatty acid methyl esters (FAME) or fatty acid ethyl esters (FAEE), respectively. Biodiesel produced by transesterification reaction by this means, three smaller molecules of ester and one molecule of glycerol are obtained from one molecule of fat or oil. Glycerol is removed as by-product and esters are known as biodiesel (Fazal et al., 2011). There are several reports on biodiesel production from edible oils (Aransiola et al., 2010). Thus; its competition with food consumption has been a global concern. About (34\%) of edible oil was estimated for worldwide biodiesel production from 2004 to 2007 (Balat, 2011), and biodiesel is projected to account for more than a third of the expected growth in edible oil use from 2005 to 2017 (Balat, 2011). Consequently, using waste and nonedible oils in biodiesel production would eliminate the competition with food consumption (Kiss, 2009), it will also allow for compliance with ecological and ethical requirements for biofuel. Non-edible oil plants are well adapted to arid, semiarid conditions and require low fertility and moisture demand to grow. Added to this, non-edible oils are not suitable for human food due to the presence of 
toxic components in the oils also they solve the problem of competition with food production (Ahmad et al., 2011).

For all these reasons, they considered non-edible oils as good raw material for biodiesel production (Ahmad et al., 2011). The most important non edible oil plants are jatropha, karanja, tobacco, mahua, neem, rubber, sea mango, castor, cotton (Azam et al., 2005). The most common plants used for biodiesel production are jatropha, moringa and castor oils.

The production of biodiesel from waste cooking oil to partially substitute petroleum diesel is one of the ways for solving the problem of illegal dumping of waste cooking oil into rivers and landfills, which lead to environmental pollution and energy shortage (Chen et al., 2009). Also, in order to reduce the cost of biodiesel production, waste cooking oil would be a good choice as raw material since it is cheaper than virgin vegetable oils and other feedstocks (Hameed et al., 2009). The used edible oil is categorized by its free fatty acid (FFA) content. If the free fatty acid content of waste cooking oil is $<15 \%$, then it is called 'yellow grease'; otherwise, it is called 'brown grease' (Kulkarni and Dalai, 2006). Microalgae as a raw material for biodiesel has been reviewed extensively in recent years. Microalgae has many advantages over other traditional sources, including soybeans (Lee, 2011), sunflower and maize oils. It is grown in open ponds, exerting zero demand on arable land. It has the potential for up to one hundred times greater biodiesel yield than from soybeans (Lee, 2011). It was considered as a good raw material source, if the cost of production of algae is favorable. Gallagher (2011) reached the same conclusion that biodiesel from algae may will become an economic reality. The use of waste animal fat for the production 
of biodiesel solves two problems that of sourcing a cheap raw material from a renewable resource that does not compete with food and that of tackling the waste management problems associated with meat production (Al-Zuhair, 2012). Previous researchers have effectively utilized mutton fat (Mutreja et al., 2011), chicken fat (Alptekin and Canakci, 2010), lard (Jeong et al., 2009) and beef tallow (Hoque et al., 2011), as alternative sources for transesterification processes. Mege et al., (2006) indicated that chicken can have a $30 \%$ fat content of the total poultry meat. The chicken fat can be simply and economically separated from wastes without chemical solvent treatment (Kondamudi et al., 2009). There are four primary ways to make biodiesel, direct use and blending, micro emulsions, thermal cracking (pyrolysis) and transesterification. The most commonly used method is transesterification of vegetable oils and animal fats (Geller and Goodrum, 2004). Transesterification or alcoholysis is the displacement of alcohol from an ester fat or oil by another in a process similar to hydrolysis, except that alcohol is used instead of water (Srivastava and Prasad, 2000). This process has been widely used to reduce the high viscosity of triglycerides. If methanol is used in this process it is called methanolysis. Methanolysis of triglyceride is represented in equation 1 ; transesterification is one of the reversible reactions and proceeds essentially by mixing the reactants. However, the presence of a catalyst (a strong acid or base) accelerates fatty acid conversion into ester. 
J. Environ. Sci.

Institute of Environmental Studies and Research - Ain Shams University

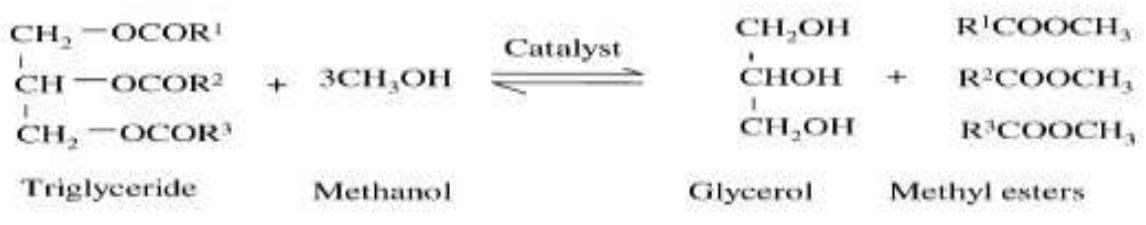

Fig. (1): General Equation for transesterification of triglycerides (1)

Transesterification of triglycerides produces fatty acid alkyl esters and glycerol as by product. The glycerol layer settles down at the bottom of the reaction vessel. Diglycerides and monoglycerides are the intermediates in this process. The mechanism of transesterification is described in equation.2, the step wise reactions are reversible and a little excess of alcohol is used to shift the equilibrium towards the formation of esters. In presence of excess alcohol, the foreword reaction is pseudo-first order and the reverse reaction is found to be second order. It was also observed that transesterification is faster when catalyzed by alkali (Özcan and Aydın, 2004). The mechanism of alkali catalyzed transesterification is described in Equation.3. The first step involves the attack of the alkoxide ion to the carbonyl carbon of the triglyceride molecule, which results in the formation of a tetrahedral intermediate. The reaction of this intermediate with an alcohol produces the alkoxide ion in the second step. In the last step the rearrangement of the tetrahedral intermediate gives rise to an ester and a diglyceride (Rojer et al., 2008).

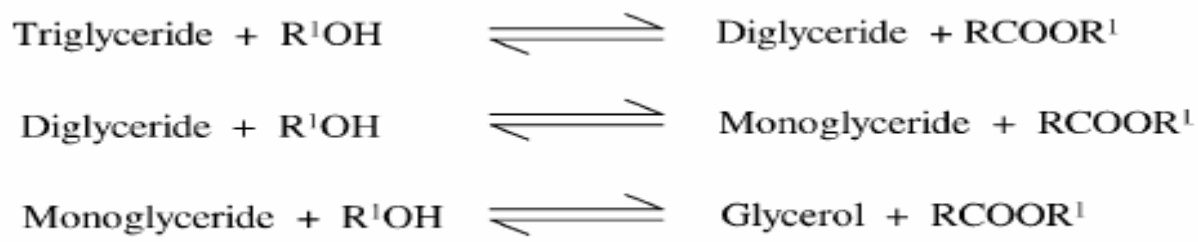

Fig. (2): Transesterification of triglycerides (2) 


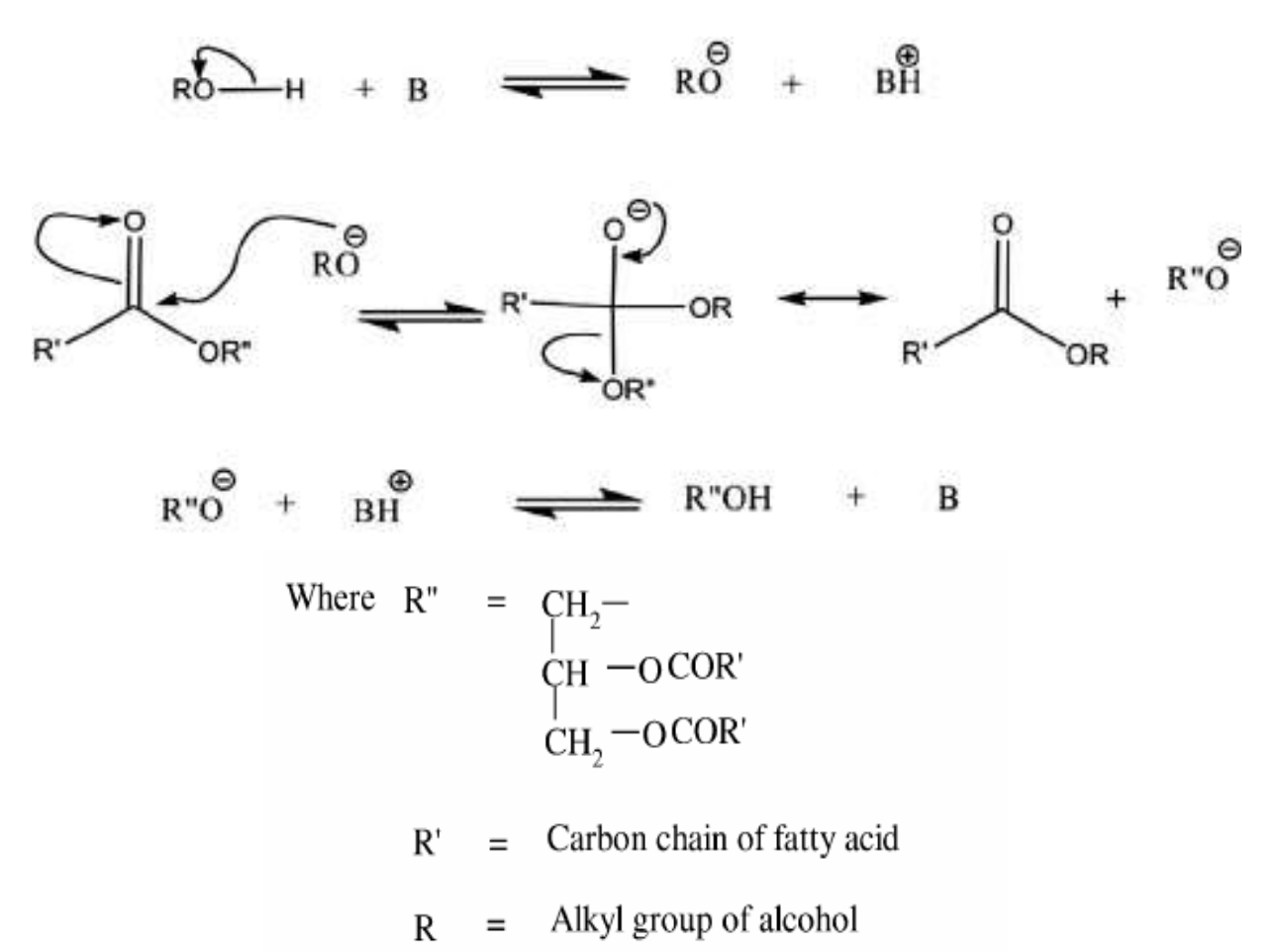

Fig. (3): Mechanism of base catalyzed transesterification (3)

The process of transesterification is affected by various factors depending upon the reaction condition used (Meher et al., 2006). These factors are free fatty acid content and moisture, catalyst type and concentration, molar ratio of alcohol to oil and type of alcohol, effect of reaction time and temperature, mixing intensity and the use of organic co-solvents.

In this work, the fat from chicken waste is suggested as a raw material for biodiesel.

The aim of the work is to produce biodiesel from chicken liquid fat resulted from roasting and investigate its characteristics as $100 \%$ biodiesel and blended with 10 and $20 \%$ with fuel oil. 


\section{MATERIALS AND METHODS}

Material: Chicken skins (source of roasting fat) were purchased from local market then heated in oven at $100{ }^{\circ} \mathrm{C}$. This chicken fat is a mixture of solid and liquid phases at room temperature. Methanol (95\%), hydrochloric acid, distilled water and sodium hydroxide (97\%) were purchased from local chemical company.

Raw-Material Extractions and Characterization: The total mass of fat obtained from skin from market was $10 \mathrm{~kg}$, showing a fat extraction yield of $35 \% \mathrm{w} / \mathrm{w}$. The acid value of obtained fat was $1.65 \mathrm{mg} \mathrm{KOH.g-1.} \mathrm{According}$ to (Selva et al., 2011)

\section{Methods:}

Acid Value: In order to access the quality of the raw material, the acid value was determined by volumetric titration according to NP EN ISO 660 (2002).

A test portion was dissolved in a solvent (ethanol at $70{ }^{\circ} \mathrm{C}$ ) and titrated with a $0.1 \mathrm{M}$ solution of potassium hydroxide, using phenolphthalein as an indicator.

Biodiesel production: The reaction started when the mixture of solid $\mathrm{NaOH}$ (97\%), dissolved in methanol $(95 \%)$ then added to the fat sample. The following reaction conditions were considered, according to the literature review: 6:1 methanol to fat molar ratio and catalyst amount $1 \%(\mathrm{w} / \mathrm{w})$. As the mass of fat considered in each reaction was $150 \mathrm{~g}$, the methanol used was 42 $\mathrm{mL}$ and the mass of catalyst $(\mathrm{NaOH})$ was $1.5 \mathrm{~g}$ at temperature $60^{\circ} \mathrm{C}$ for about 90 minutes according to (Moreira et al., 2009)

Biodiesel yield of each reaction was determined based on the following equation: 
biodesiel yield $=\frac{\text { mass of biodiesel }}{\text { mass of raw material }} \times 100$

After the reaction is completed, the mixture of Biodiesel and glycerol was placed in a separating funnel.

Biodiesel Purification: After separation of biodiesel and glycerol, biodiesel was washed to remove the residual catalyst. First, $75 \mathrm{~mL}$ of a diluted solution of $\mathrm{HCl}(0.2 \%)$ was added to the biodiesel, then, the same amount of distilled water was repeatedly used to wash the biodiesel and ensure total removal of acid/base and salts. The washing process was stopped when the initial distilled water $\mathrm{pH}$ was similar to the $\mathrm{pH}$ of the water after extraction. After this washing process, biodiesel was heated at $90{ }^{\circ} \mathrm{C}$ to evaporate the water and alcohol present. Finally, the purified product was weighed and placed in the refrigerator (Moreira et al., 2009).

Biodiesel Characteristics: The raw materials and the production process variables strongly influence biodiesel quality. To ensure and control product quality, standards were established and carried out according to (ASTM D6751, 2002).

\section{RESULTS AND DISSCUSION}

Biodiesel Composition: Biodiesel composition reflects the raw material composition and was determined using gas chromatography. The fatty acid profile for liquid fat resulted from roasting was as shown in table (1). 
J. Environ. Sci.

Institute of Environmental Studies and Research - Ain Shams University

Table (1): Fatty acid profile for liquid fat resulted from roasting

\begin{tabular}{|c|c|c|}
\hline Fatty acid & aC:bN & Weight \% \\
\hline Palmitic acid & $16: 0$ & 26.4577 \\
\hline Stearic acid & $18: 0$ & 7.2234 \\
\hline Plmitoliec acid & $16: 1$ & 3.5379 \\
\hline Oleic acid & $18: 1$ & 62.781 \\
\hline
\end{tabular}

${ }^{\mathrm{a}} \mathrm{C}$, no of carbon, ${ }^{\mathrm{b}} \mathrm{N}$, no of carbon-carbon double bond

Oleic fatty acid was the one presented in higher quantity.

Table (2): Comparison between fatty acid profile of chicken fat for present study with other previous studies

\begin{tabular}{|c|c|c|c|c|c|c|}
\hline Fatty acid & $\begin{array}{c}\text { Present } \\
\text { study }\end{array}$ & $\begin{array}{l}\text { Marulanda et } \\
\text { al. (2010) }\end{array}$ & $\begin{array}{l}\text { Arnaud et } \\
\text { al. (2004) }\end{array}$ & $\begin{array}{c}\text { Boey } e t \\
\text { al.(2011) }\end{array}$ & $\begin{array}{c}\text { Lee and } \\
\text { Foglia } \\
(2000) \\
\end{array}$ & $\begin{array}{c}\text { Moreira } \\
\text { et } \\
\text { al.(2009) }\end{array}$ \\
\hline $\begin{array}{c}\text { Palmitic } \\
\text { acid } \\
16: 0\end{array}$ & 26.45 & 21 & 24 & 24.7 & 25.2 & 24.85 \\
\hline $\begin{array}{c}\text { Stearic } \\
\text { acid } \\
18: 0\end{array}$ & 7.22 & 5.5 & 5.8 & 4.5 & 5.9 & 6.23 \\
\hline $\begin{array}{c}\text { Plmitoliec } \\
\text { acid } \\
16: 1\end{array}$ & 3.53 & 7.7 & 5.8 & 6.3 & 7.8 & 6.13 \\
\hline $\begin{array}{c}\text { Oleic acid } \\
18: 1\end{array}$ & 62.78 & 48.5 & 38.2 & 44.1 & 40.5 & 41.19 \\
\hline $\begin{array}{c}\text { Linolenic } \\
\text { acid } \\
18: 3\end{array}$ & $\begin{array}{c}\text { Not } \\
\text { detected }\end{array}$ & Traces & 1.9 & 0.2 & 0.7 & $\begin{array}{c}\text { Not } \\
\text { detected }\end{array}$ \\
\hline
\end{tabular}

The fatty acid profile for current work is $33.67 \%$ for saturated fatty acid while the fatty acid profile for saturated fatty acid for (Marulanda et al., 2010 \& Arnaud et al., 2004 \& Boey et al., 2011 \& Lee and Foglia, 2000 and

Moreira et al., 2009) was 26.5 \%, $29.8 \%, 29.2 \%, 31.1 \%$ and $31.08 \%$ respectively. On the other hand the fatty acid content for unsaturated fatty acid for present study is $66.31 \%$, while that for (Marulanda et al., 2010, 
Arnaud et al., 2004, Boey et al., 2011, Lee and Foglia, 2000 and Moreira et al., 2009) was $56.2 \%, 45.9 \%, 50.6 \%, 48.9 \%$ and $47.32 \%$ respectively with major components being palmitic, stearic, linoleic, and oleic acids like that for (Gugule et al., 2011).

Table (3): Quality control parameters of biodiesel resulted from liquid fat upon roasting for current work and others' work

\begin{tabular}{|c|c|c|c|c|c|c|}
\hline Test & Method & $\begin{array}{c}\text { ASTM } \\
\text { D6751 } \\
\text { Standards }\end{array}$ & $\begin{array}{c}\text { CFME } \\
\text { for } \\
\text { current } \\
\text { work } \\
\end{array}$ & $\begin{array}{c}\text { Kambiz } \\
\text { et al., } \\
\text { (2011) }\end{array}$ & $\begin{array}{c}\text { Selva \& } \\
\text { Lima., } \\
(2011)\end{array}$ & $\begin{array}{c}\text { Moreira et } \\
\text { al.(2009) }\end{array}$ \\
\hline $\begin{array}{c}\text { Density @ } \\
15.56 \mathrm{oC} \\
\end{array}$ & $\begin{array}{c}\text { ASTM D- } \\
1298 \\
\end{array}$ & & 0.8724 & 0.864 & 0.870 & $0.878-0.885$ \\
\hline Pour Point, oC & $\begin{array}{l}\text { ASTM D- } \\
97\end{array}$ & NA & 0 & ---- & ---------- & $170-178$ \\
\hline Flash Point, oC & $\begin{array}{l}\text { ASTM D- } \\
93\end{array}$ & $130 \mathrm{~min}$ & 190 & $\cdots \cdots$ & $\ldots \ldots$ & $\cdots \cdots$ \\
\hline $\begin{array}{c}\text { Carbon } \\
\text { Residue, wt } \% \\
\end{array}$ & $\begin{array}{l}\text { ASTM D- } \\
527 \\
\end{array}$ & $0.050 \max$ & Nil & $\ldots \ldots$ & $\ldots \ldots$ & .... \\
\hline $\begin{array}{c}\text { Kinematic } \\
\text { viscosity @ } \\
40 \mathrm{oC}, \mathrm{cSt}\end{array}$ & $\begin{array}{l}\text { ASTM D- } \\
445\end{array}$ & $1.9-6$ & 4.83 & 5.5 & 4.3 & $4.52-6.13$ \\
\hline Cetane Index & $\begin{array}{l}\text { ASTM D- } \\
976\end{array}$ & $47 \mathrm{~min}$ & 64.65 & ...... & $\ldots$ & \\
\hline $\begin{array}{c}\text { Total acid } \\
\text { number, mg } \\
\text { KOH/ gm } \\
\end{array}$ & $\begin{array}{l}\text { ASTM D- } \\
\quad 664\end{array}$ & $0.8 \max$ & 0.178 & ----- & 0.16 & 0.091-0.24 \\
\hline $\begin{array}{c}\text { Total Sulphur, } \\
\text { wt } \%\end{array}$ & $\begin{array}{c}\text { ASTM D- } \\
4294\end{array}$ & $0.0015 \max$ & Nil & ses & $\ldots$ & $\ldots \ldots$ \\
\hline $\begin{array}{l}\text { Copper } \\
\text { corrosion }\end{array}$ & $\begin{array}{c}\text { ASTM D- } \\
130\end{array}$ & No.3 max & $1 \mathrm{a}$ & ........ & .. & $\ldots \ldots$ \\
\hline
\end{tabular}

According to data tabulated in table (3) all results are compliance with ASTM D6751(2002) standards, Density @ $15.56^{\circ} \mathrm{C}$ for current work was near other results for (Kambiz et al., 2011,Selva and Lima, 2011 and Moreira et $a l ., 2009)$ which were $0.864,0.870$ and 0.878 respectively, while the value of Flash Point, ${ }^{\circ} \mathrm{C}$ for current work higher than that for (Moreira et al.,2009) which was $\left(170-178{ }^{\circ} \mathrm{C}\right)$, Kinematic viscosity @ 40 $\mathrm{C}$, cSt value for current 
J. Environ. Sci.

Institute of Environmental Studies and Research - Ain Shams University

work was compliance with ASTM D6751(2002) standards as that for other authors (Kambiz et al., 2011, Selva and Lima, 2011 and Moreira et al., 2009) and Total acid number, mg $\mathrm{KOH} / \mathrm{gm}$ was in agreement of with ASTM standards for current work and for (Selva and Lima, 2011 and Moreira et al., 2009).

Table (4): Quality control parameters of biodiesel resulted from liquid fat upon roasting after blending with petrodiesel

\begin{tabular}{|c|c|c|c|c|}
\hline Test & Method & $\begin{array}{c}\text { ASTM D7467 } \\
\text { Standards }\end{array}$ & $\begin{array}{c}\text { CFME from } \\
\text { liquid fat upon } \\
\text { roasting(B10) }\end{array}$ & $\begin{array}{c}\text { CFME from liquid } \\
\text { fat upon } \\
\text { roasting(B20) }\end{array}$ \\
\hline \hline $\begin{array}{c}\text { Density @ } \\
\text { 15.56oC }\end{array}$ & ASTM D-1298 & $\ldots \ldots \ldots$ & 0.8315 & 0.9071 \\
\hline $\begin{array}{c}\text { Total acid } \\
\text { number, mg } \\
\text { KOH/gm }\end{array}$ & ASTM D-664 & $0.3 \max$ & 0.056 & 0.0594 \\
\hline $\begin{array}{c}\text { Total Sulphur, wt } \\
\%\end{array}$ & ASTM D-4294 & $\begin{array}{c}15 \max (\mathrm{S} 15) \\
500 \max (\mathrm{S} 500)\end{array}$ & 0.081 & 0.072 \\
\hline $\begin{array}{c}\text { Kinematic } \\
\text { viscosity } \\
\text { @ 40oC,cSt }\end{array}$ & ASTM D-445 & $1.9-4.1$ & 3.1 & 3.32 \\
\hline Pour point, ${ }^{\circ} \mathrm{C}$ & ASTM D-97 & $\ldots \ldots \ldots$. & -6 & -6 \\
\hline Flash point, ${ }^{\circ} \mathrm{C}$ & ASTM D-93 & 52 min & 91 & Nil \\
\hline $\begin{array}{c}\text { Carbon residue, } \\
\text { wt.\% }\end{array}$ & ASTM D-189 & $\ldots \ldots \ldots$ & Nil & $1 \mathrm{a}$ \\
\hline Copper corrosion & ASTM D-130 & No.3 max & $1 \mathrm{a}$ & 56 \\
\hline Cetane Index & ASTM D-976 & $40 \min$ & 59 & 95 \\
\hline
\end{tabular}

According to data tabulated in table (4) all results in are compliance with ASTM D7467 Standards.

Biodiesel Production Yield: From an economical perspective, biodiesel production yield is very important. The yield was determined considering the initial poultry fat mass $(150 \mathrm{~g})$ and the mass of biodiesel obtained after the reaction. The yield obtained was calculated using the following equation: 


$$
\text { biodesiel yield }=\frac{\text { mass of biodiesel }}{\text { mass of raw material }} \times 100
$$

(1) The obtained yeild was $79.1 \%$ for liquid fat resulted from roasting There are a few reasons for the low yield achieved:

- Formation of emulsions that hinder the washing process during purification;

- Drag of some biodiesel during this phase;

- Presence of water that leads to hydrolysis of triglycerides and consequently formation of FFA that react with $\mathrm{NaOH}$ forming soaps.

Regarding the raw material used, the results showed that biodiesel production using raw material containing free fatty acids by conventional process is possible, without any pre-treatment, contrary to the results obtained in other studies; however it brings many operational problems and difficulty for the reproducibility of the experiments. Therefore, the storage and the processing of the fat is a key issue.

\section{CONCLUSION}

Results of the present study clearly demonstrated that the use of chicken fats is very suitable as low cost feed stocks for biodiesel production as all results are compliance with ASTM standards. The optimal reaction conditions for production of methyl esters from chicken and are established as follows. The reaction time of $90 \mathrm{~min}$ at $60 \mathrm{oC}, 6: 1$ molar ratio of methanol to oil and $1 \% \mathrm{NaOH}$ w/w of fat weight of chicken fat which is $150 \mathrm{gm}$ of chicken fat. 
J. Environ. Sci.

Institute of Environmental Studies and Research - Ain Shams University

\section{REFERENCES}

Ahmad, A. L.; Yasin, N. H. M.; Derek, C. J. C.; and Lim, J. K. (2011): 'Microalgae as a Sustainable Energy Source for Biodiesel production: A Review', Renewable and Sustainable Energy Reviews, Vol. 15, N¹, $584-593$.

Alptekin, E. and Canakci, M. (2010): Optimization of pre-treatment reaction or methyl ester production from chicken fat. Fuel. 89, 4035-4039.

Al-Zuhair, S.; Hussein, A.; Al-Marzouqi, A. H. and Hashim, I. (2012): Continuous production of biodiesel from fat extracted from lamb meat in supercritical CO2 media. BiochemEng 60,106-10.

Aransiola, E.; Betiku, E.; Layokun, S. and Solomon, B. (2010): Production of biodiesel by transesterification of refined soybean oil. IJBCS 4(2), 391-9.

Arnaud, E.; Relkin, P.; Pina, M. and Collignan, A. (2004): Characterization of chicken fat dry fractionation at the pilot scale. Eur. F. Lipid Science Technology, 106, 591-598.

ASTM, Standard Specification for Biodiesel Fuel (B100) Blend Stock for Distillate Fuels, Designation D 6751-6802, (2002): ASTM International, West Conshohocken, PA.

ASTM D7467-18a (2018): Standard Specification for Diesel Fuel Oil, Biodiesel Blend (B6 to B20), ASTM International, West Conshohocken, PA.

ASTM D7467, Specification for Diesel Fuel Oil, Biodiesel Blend (B6 to 20) a completely new specification that covers finished fuel blends of between 6 (B6) and 20 (B20) percent biodiesel for on- and offroad diesel engine use.

Azam, M. M.; Amtul, W. and Nahar, N. M. (2005): 'Prospects and Potential of Fatty Acid Methyl Esters of Some Non-Traditional Seed Oils for Use as Biodiesel in India', Biomass and Bioenergy, Vol. 29, $\mathrm{N}^{\circ} 4,293-302$. 
Balat, M. (2011): Potential alternatives to edible oils for biodiesel production e a review of current work. Energy Convers Manag .52(2), 147992.

Bhatti, H. N.; Hanif, M. A.; Qasim, M. and Rehman, A. U. (2008): Biodiesel production from waste tallow. Fuel, Vol.87, N.13-14, (October 2008), 2961-2966, ISSN 0016-2361.

Boey, P. L.; Maniam, G. P.; Hamid, S. A. and Ali, D. M. H. (2011): Crab and cockle shells as catalysts for the preparation of methyl esters from low free fatty acid chicken fat. J. Am. Oil Chem. Soc. 88, 283288.

Carlsson, A. S. (2009): Plant oils as feedstock alternatives to petroleum A short survey of potential oil crop platforms. Biochimie, Vol.91, No.6, (June 2009), 665-670, ISSN 0300-9084

Chen, Y.; Xiaom, B.; Chang, J.; Fu, Y. L. P. and Wang, X. (2009): 'Synthesis of Biodiesel from Waste Cooking Oil Using Immobilized Lipase in Fixed Bed Reactor', Energy Conversion and Management, Vol. $50, \mathrm{~N}^{\circ} 3,668-673$.

Fazal, M. A.; Haseeb, A. S. M. A. and Masjuki, H. H. (2011): Biodiesel feasibility study: An evaluation of material compatibility; performance; emission and engine durability. Renewable \& Sustainable Energy Reviews, Vol.15, No.2, (February 2011), 1314-1324, ISSN 1364-0321

Gallagher, B. J. (2011): The economics of producing biodiesel from algae. Renew Energy 36(1):158-62.

Geller, D. P. and Goodrum, J. W. (2004): Fuel. 83: 17-18: 2351-2356.

Gugule, S.; Fatimah, F. and Rampoh, Y. (2011): The utilization of chicken fat as alternative raw material for biodiesel synthesis. Animal Production. 13, 115-121.

Hameed, B. H.; Goh, C. S.; and Chin, L. H. (2009): 'Process Optimization for Methyl Ester Production from Waste Cooking Oil Using Activated Carbon Supported Potassium Fluoride', Fuel Processing Technology, Vol. 90, N $12,1532-1537$. 
Hoque, M. E.; Singh, A. and Chuan, Y. L. (2011): Biodiesel from low cost feedstocks: The effects of process parameters on the biodiesel yield. Biomass Bioenergy. 35, 1582-1587.

Jeong, G. T.; Yang, H. S. and Park, D. H. (2009): Optimization of transesterification of animal fat ester using response surface methodology. Bioresour.Technol. 100, 25-30.

Kambiz Tahvildari A.; Narges Davari B.; Mohammadreza Allahgholi Ghasri C. and Masoomeh Behrourzinavid D.: Biodiesel Production from Waste Chicken Fat based Sources International Journal of Chemical, Molecular, Nuclear, Materials and Metallurgical Engineering Vol:5 No: 7(2011).

Kiss, A .A. (2009): Novel process for biodiesel by reactive absorption. Sep PurifTechnol 69(3):280-7.

Kondamudi, N.; Strull, J.; Misra, M. and Mohapatra, S. K. (2009): A green process for producing biodiesel from feather meal. J. Agric. Food Chem. 57, 6163-6166.

Kulkarni, M. G. and Dalai, A. K. (2006): 'Waste Cooking Oils An Economical Source for Biodiesel: A Review', Industrial and Engineering Chemistry Research, Vol. 45, N9, 2901 - 2913, 2006.

Lee, D. (2011): Algal biodiesel economy and competition among biofuels. BioresourTechnol 102(1):43-9.

Lee, K. and Foglia, T. A.: Synthesis, purification, and characterization of structured lipids produced from chicken fat. Article in Journal of the American Oil Chemists' Society 77(10), 1027-1034 , (2000).

Marulanda, V. F.; Anitescu, G. and Tavlarides, L. L: Investigations on supercriticaltransesterification of chicken fat for biodiesel production from low-cost lipid feedstocks. The Journal of Supercritical Fluids. 54, 53-60, (2010).

Mege, R. A.; Manalu, W.; Kusumorini, N. and Nasution, S. H. (2006): Pengaruhsuperovulasiterhadapproduksianakbabi. J. Anim. Prod. 8, 14-18. 
Meher, L. C.; VidyaSagar, D. and Naik, S. N. ( 2006): Technical aspects of biodiesel production by transesterification a review, Renewable and sustainable energy reviews. 10, 3, 248-268.

Moreira, I.; Mourinho, F. L.; Carvalho, P. L. de O.; Paiano, D.; Piano, L. M. and Junior, I. S. K. (2009): Avaliação nutricional da casca de soja com ou sem complexo enzimático na alimentação de leitões na fase inicial. Rev. Bras. Zootec., 38 (12), 2408-2416.

Mutreja, V.; Singh, S. and Ali, A. (2011): Biodiesel from mutton fat using $\mathrm{KOH}$ impregnated $\mathrm{MgO}$ as heterogeneous catalysts. Renewable Energy. 36, 2253-2258.

NP EN ISO 660 standard (2002): Acid value determined by volumetric titration.

Özcan, M. and Aydın, C. (2004): Physico-mechanical Properties and Chemical Analysis of Raw and Brined Caperberries, Biosystems Engineering. 89, 4, 521-524.

Rojer, C.; Prince, C. H. and Catherine, C. L. (2008): Chemosfere. 71, 8, 1446- 1451.

Selva, I. P.; Parthiban, R. and Lima, R. M. (2011): Poultry Fat A Cheap and Viable Source for Biodiesel Production. 2nd International Conference on Environmental Science and Technology IPCBEE vol.6 IACSIT Press, Singapore.

Srivastava, A. and Prasad, R. (2000): Triglycerides-based diesel fuels. Renew sustain energy reviews. 4, 2, 111-133. 
J. Environ. Sci.

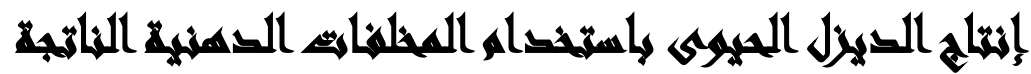

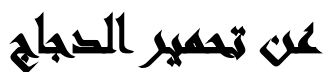

[r]

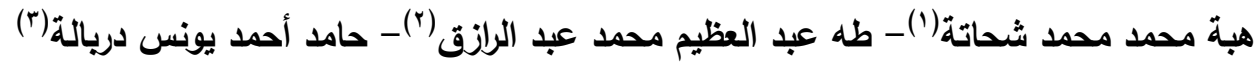

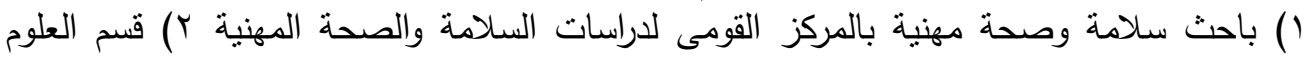

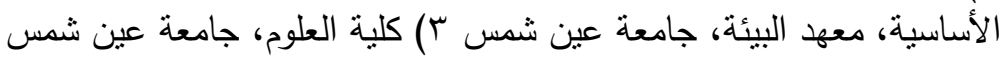

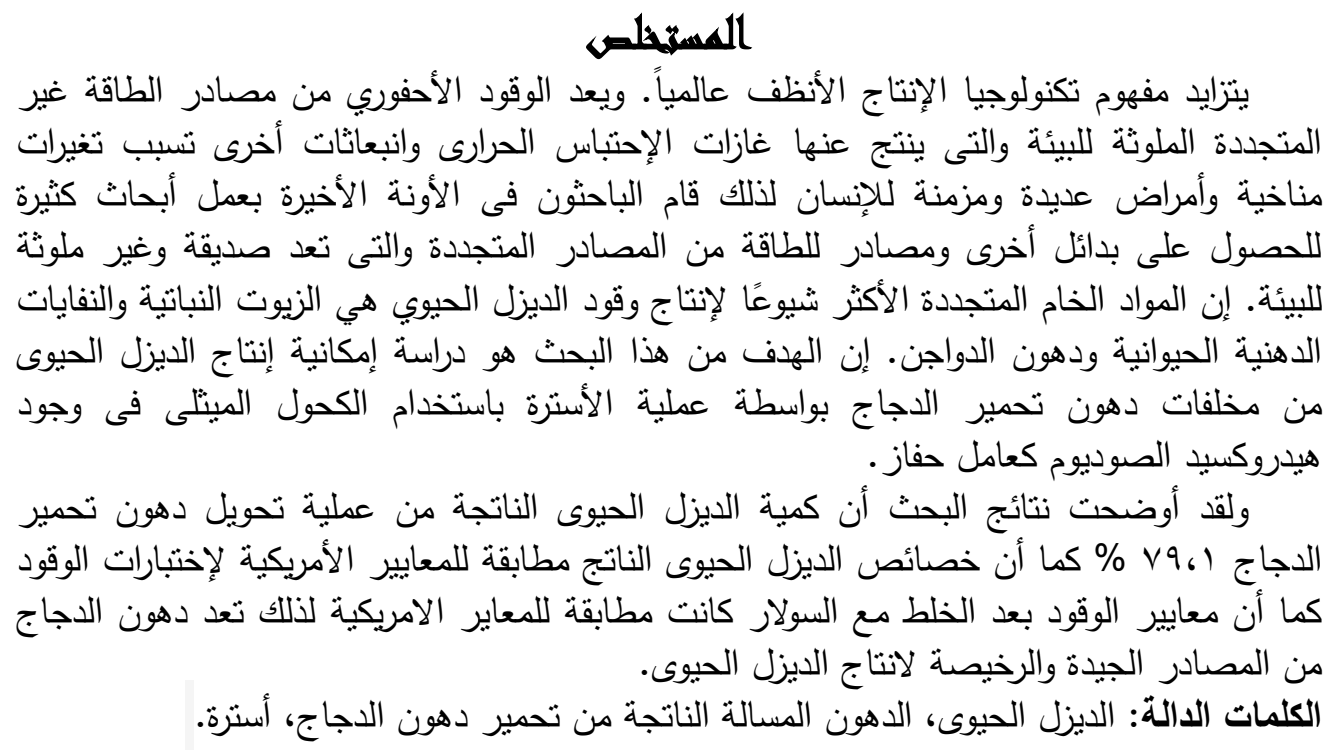

